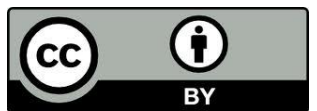

\title{
Escolas de fé e fé nas escolas
}

\author{
Faith schools and faith schools
}

\author{
João Ferreira Santiago \\ Bacharel em Teologia e Mestre em Teologia pela PUCPR \\ poesiaemilitancia@yahoo.com.br
}

RESUMO: A vida é uma escola, diz a sabedoria popular. Nela já nascemos matriculados e não podemos fugir ou nos negar a participar. Não é a única, mas é a mais importante. Tem, no entanto, muitas outras escolas que lhe auxiliam e lhe complementam, mas três são as mais significativas: a família, a religião e a escola formal. Todas padecem, no entanto, a crise de sentido pela qual passa a sociedade atual. A família é a escola que nos ensina o essencial à vida: amar, ser amado, a perdoar e a dar sentido à vida. Inclusive nela aprendemos a ter uma religião e a partir dela fazemos a matrícula na escola formal, a única obrigatória por força de lei. A religião é a escola que nos ensina a transcender à racionalidade e buscar uma relação mística com o Ser Superior. Diferentemente do que é mostrado hoje pelas diversas religiões, é muito mais que simplesmente ir à Igreja. A escola formal é geralmente a que nos introduz na sociedade e na cultura nas quais vivemos. Apesar de serem escolas complementares, a escola formal vive em constante conflito com a família e com a religião.

Palavras Chave: Vida família; Religião; Escola.

ABSTRACT: Life is a school, says the conventional wisdom. Enrolled in it are born and we can not escape or deny us participate. Is not the only, but it is the most important. It has, however, many other schools that will help you and complement, but three are the most significant: the family, religion and school formal. All suffer, however, the crisis of meaning through which passes the current society. The family is the school that teaches the essentials for life: to love, be loved, to forgive and to give meaning to life. Even her learn to have a religion and from it we enrollment in formal school, the only mandatory by law. Religion is a school that teaches us to transcend rationality and seek a mystical relationship with the Supreme Being. Unlike what is shown today by the various religions, is much more than just going to church. The formal school is usually that brings us into the society and culture in which we live. Despite being supplementary schools, formal school live in constant conflict with family and religion.

Keywords: Family life; Religion; School. 


\section{Introdução}

Este artigo se propõe a tratar e efetivamente trata da vida. Não da vida como um conceito abstrato, mas da vida como realidade. Tratar da vida é mais comprometedor que simplesmente escrever um artigo científico. Assim, para este texto, a vida é, em primeiro lugar, uma escola. Mas também não se trata de uma escola formal, encaixada dentro de regras, de horários e livros de chamada, onde se ensinam disciplinas e doutrinas, mas de uma escola onde se aprende. Tampouco se trata de uma escola informal. Esta escola, onde já nascemos matriculados e ninguém pode nos expulsar dela, ou nos proibir de participar, a não ser que se auto delegue o direito sobre a vida, é uma universidade. Tem muitas, escolas e muitas formas de ensinar, mas três são as principais escolas auxiliares que lhe dão suporte. Pela ordem hierárquica são elas: a família, a religião e a escola formal. Este artigo também quer mostrar uma visão crítica, jamais criticista, destas escolas auxiliares da escola da vida, e realmente o faz, sobretudo e de maneira serena, denuncia seus desvios e aponta as possíveis causas destes. Realisticamente falando o ser humano não sobreviveria não fosse a família, e nela de forma especial a mãe, de quem é absolutamente dependente nos primeiros anos de vida. Por isto, por causa destas questões, tratamos a família para além dos laços sanguíneos. Em última instância e em primeira ordem, trata-se da família humana. A escola chamada religião, com as virtudes teologais, a fé, a esperança e a caridade, é quem nos ensina a transcender às fronteiras da mundanidade e dar sempre novo sentido à própria vida. A teologia oficial da Igreja, é sacerdotal, estática, vive em função de manter tudo como estar e ultrapassa os limites da serenidade para calar, punir e anular qualquer vontade profética de mudança em suas estruturas. Quando a religião deixa de dar sentido à vida, deixa também de ter sentido. A escola formal, como dever do Estado, é a única que é obrigatória por força de lei, até pode perverter o que aprendemos nas outras escolas, mas não as pode superar nem as substituir. É de complementaridade, portanto, a relação entre estas escolas.

A vida é uma escola, diz a sabedoria popular. De fato, mas não é a única. $\mathrm{Ou}$ será? Temos muitas escolas na vida, ou o que temos são diversos cursos, diversas salas de aula, com as mais diversas temáticas, na mesma escola-vida? A vida é a principal escola, à qual já nascemos matriculados, coadjuvada por outras escolas nas quais poderemos nos matricular opcionalmente? Seja como for que as vejamos, se como salas 
de aula, como cursos complementares, da escola-vida, ou como escolas opcionais, secundárias, parecem ser estes três os principais espaços de aprendizagem. A família, a religião e a escola formal, esta última, a única que é obrigatória por força de lei. Todas interferem, cada uma a seu modo, formando nossos referenciais de vida, nossa visão de mundo, nossos valores políticos, morais, humanos, religiosos, e por isso mesmo, nossa espiritualidade. Escondem ou revelam traços nossos, comportamentos, posturas e valores que só elas podem esconder ou revelar. São elas, a nosso ver, pela ordem de hierarquia, a família, a religião e a escola formal. Esta última, aonde aprendemos principalmente a ler, escrever e fazer conta, mas que precisa ser também uma escola de formação política. Tudo isto é válido, é visível e pode ser facilmente comprovado. Que cada uma tenha sua função específica cumpra seu papel e tenha seu lugar, também nos parece razoável, mas, o que cada uma delas tem que ver com as outras? Nenhuma delas sozinha pode dá conta formando uma parte do ser humano, mas cada uma delas e todas ao mesmo tempo, devem formar o ser humano todo, na sua complexidade. A escolavida, através de suas escolas auxiliares, ou de seus cursos específicos, mais que isto, deve formar, no sentido de promover, todos os seres humanos e os seres humanos todos, como bem diz o Papa Paulo VI, (PP 14).

Aprender, a gente sempre aprende. De um jeito ou de outro, a gente sempre aprende. É impossível viver sem aprender. Não por acaso a sabedoria popular nos diz que a vida é uma escola e ela realmente o é. Não cobra uma mensalidade fixa, numa moeda definida, mas de alguma forma nos cobra. Não nos faz chamada sistemática, nem reprova por faltas, mas de alguma forma sempre registra as nossas faltas. Não somos apenas avaliados, mas o somos constantemente. Não nos fornece diploma de formatura, nem faz se quer uma prova final, mas sempre nos avalia e também nos certifica. Na verdade, a escola-vida exige de nós que nos avaliemos. Consciente ou inconscientemente todos/as nós fazemos isto, a toda hora. Nenhuma avaliação, no entanto, é tão impactante quanto àquela que nós mesmos nos fazemos. A auto avaliação é quem deve nos dizer onde, quando e como devemos mudar, mas isto nos exige mais que o senso de dever, nos exige maturidade, comprometimento e responsabilidade. A escola-vida sabe disto. Somente ela nos ensina que devemos ser o melhor que podermos ser, e não apenas melhor que alguém. As outras escolas nos ensinam a fazer comparações, a competir, nelas o que temos muitas vezes é que superar o outro, pouco 
importando se às vezes, permanecemos egoístas. Se para vencê-lo, superando-o nas avaliações, temos que diminuí-lo. Às vezes, eliminá-los.

Na escola da vida, ou na escola-vida, a primeira e principal escola que temos, não tem jeito, todos/as somos matriculados automaticamente. Às suas aulas frequentamos religiosamente, mesmo que às vezes, finjamos não frequentá-las. Aliás, são também as religiões escolas de vida. Escolas de fé, e neste sentido, por estas razoes, não pode haver dicotomia entre a fé e a vida. Assim, ou a educação, seja ela aonde for, respeita a fé de quem a busca encontrar, ou estará desrespeitando a própria pessoa. A fé é uma virtude na escola-vida, apesar de parecer ser restrita às religiões. A fé aprende-se também nas religiões, mas está para além de suas denominações.

A segunda escola, ou a principal sala de aula da escola-vida, da qual carregamos traços e marcas indeléveis, é a família. É ela quem nos introduz na escola-vida, lá estão nossos maiores mestres e nossas mais sábias mestras. E é nela também que aprendemos o essencial à vida. Amar, deixar-se amar e sentir-se amado, dialogar e conviver com opiniões diferentes. Aprendemos a cuidar dos idosos, dos doentes, principalmente pelo exemplo. São eles que cuidam de nós, na infância, na adolescência, na doença e por toda a nossa vida. Raramente nos dizem isto, mas é na família, sobretudo na convivência entre irmãos, que aprendemos que até as pessoas que nos amam, inevitavelmente, vez ou outra nos machucam. Desta lição nasce outra maior, a capacidade de perdoar. Aprendemos que precisamos perdoá-los quando isto acontece. A família é também um porto seguro para onde voltamos sempre que nos damos mal nas aventuras ou nos desafios que enfrentamos na vida. É nela que nos tornamos especialistas em vida. Nos momentos históricos de repressão e de violência isto se torna muito visível. O testemunho das famílias quilombolas fala por si.

Foi e é na família constituída por laços de sangue ou por identidade que a população negra viveu e resistiu à escravidão, ao racismo, à exploração, à perseguição. As famílias desfeitas no período escravista deram lugar a outras famílias que uniam povos de regiões diferentes da África, com línguas e crenças diferentes, numa união pela saudade da terra, da casa, da família, como reunir-se para sobreviver, resistir e lutar com laços familiares reconstruídos e ressignificados (MEC/SECAD, 2006, p. 41). 
É assim que nos descobrimos pertencentes a uma escola chamada família, que aprendemos com o tempo a chamá-la de comunidade. As circunstâncias e as aulas nesta escola, se bem integrada à escola vida, nos ensinam que ser família é mais que uma questão sanguínea. É dela que levamos os principais aprendizados para outras comunidades que viermos a construir ou fazer parte. Este é o caminho para chegarmos ao conceito de família humana e isto deve nos levar à superação do preconceito e da discriminação. Os laços que nos unem e nos levam a ter e defender o sentimento de pertença são diversos, mas passam pela compreensão da família como escola. É na escola-família que aprendemos, por exemplo, a ter uma religião. Apesar de nem sempre nos ensinar a ser religioso. Ser religioso desperta a nossa espiritualidade, ter apenas religião a amortece frequentemente. A relação mística entre a família e a Igreja, no meio da qual acontece a vida da religião, sobretudo saber quem é quem, apesar de representar a teologia oficial, que pensa a partir da estrutura e defende a sua manutenção, diz a CNBB,

Deus, criador de tudo, criou o homem e a mulher como efusão de seu amor. Amou-os infinitamente e lhes deu uma vocação ao amor e à comunhão. A família, consequência dessa vocação, é dentre todas as obras, a obra predileta de Deus nesse seu projeto de amor. Ela não é criação humana, nem do Estado, nem da Igreja. É constitutivamente ligada à natureza do homem e da mulher, para o bem e a felicidade pessoal, da sociedade e da Igreja (CNBB, DOC 79, p. 51).

A religião é, portanto, segundo nossa ordem, a terceira escola nessa hierarquia, sendo a segunda dentro da grande escola-vida. É verdade, que o conceito de família utilizado pelas religiões não atende mais à realidade de nosso tempo, concordamos com isto, mas não vamos avançar nestas veredas neste texto. A religião é uma escola aonde se aprende o significado de aprender. Por nascer de uma árvore frondosa e de raízes profundas e bem fincadas no chão da história humana, chamada cultura, a religião se expressa dentro e a partir das culturas. "A religião enquanto interesse último é a substância que-dá-sentido à cultura, e a cultura é a totalidade das formas por meio das quais o interesse fundamental da religião exprime a si mesmo". (Tillich, 1959, p. 90). 
Esta relação ontológica, nem sempre mostrada na vivência do dia a dia da religião, faznos soar estranho pensar a religião como escola. Mas tem saberes que só as religiões podem nos ensinar com propriedade. É por isso também que, quando as religiões ficam excessivamente hierárquicas, exageradamente doutrinadoras, desvirtuam sua vocação de escola de fé. Quando a religião deixa de dar significado à vida e confronta-se com ela ao invés de com ela colaborar ajudando-nos também a encontrar significado e sentido, naquilo que fazemos, dizemos que ela está doente. Religião vista como "religare", parece querer sempre nos religar a algo que a gente despercebidamente tende a se afastar, mas não pode viver sem. É como se ela fosse um colete salva vidas e nós fôssemos aprendizes de natação, colocados em alto mar. Cada vez que a gente começa a se afogar, que respirar vai ficando cada vez mais difícil e viver incerto, ela nos religa ao oxigênio vital e assim voltamos a respirar.

Nadar, aqui, não é o interesse último, citado por Tillich, nem mesmo respirar, mas viver. No entanto, neste caso, não é a religião o sentido em si, mas a vida, para a qual ela aponta e deve dar sentido. O sentido último está no inominável, no indecifrável, no oceano de onde emergem e para onde correm, como se fossem rios, as religiões. Estas são as únicas que podem dá este sentido, porque nos religam a Ele sempre que dele nos afastamos. O Sagrado, o Ser supremo, recebe as mais variáveis denominações, de uma religião ou de uma cultura para outra, ou mesmo dentro da mesma religião. São tentativas humanas de dizer o mínimo do Ser Superior que os cristãos, por exemplo, o chamam de Deus. Este Ser, que acreditamos ser o Criador da escola-vida, é também o seu Reitor e Grande Mestre. É significativo neste sentido o diálogo de Jesus com Marta, no episódio da Ressurreição de Lazaro, onde Deus e a Vida são o mesmo Ser, são sinônimos, "Eu sou a Ressurreição e a Vida: aquele que crer em mim, mesmo que morra, viverá; e todo aquele que vive e crer em mim, não morrerá jamais”, (Jo 11, 25). A religião vista como escola de fé, fé em Deus, mas também Fé na vida, fé na gente, na força da solidariedade radicalizada.

É de se imaginar esse diálogo mais que significativo ter acontecido entre quatro jovens de um grupo bem maior. Jesus era amigo de Marta, de Maria e de Lázaro, o motivo deste diálogo, e é presumível que partilhassem os mesmos sonhos, falassem dos mesmos assuntos, enfim, lutassem pelas mesmas causas. Talvez sonhassem com a organização do povo vencendo a repressão romana, o autoritarismo, o jogo de 
conveniência e a desfaçatez das autoridades religiosas de seu tempo. Às vezes imagino estas cenas quando vejo as reuniões das Comunidades Eclesiais de Base - CEBs; do Grupo Juventude Base e Luta - GBL; e da Pastoral da Juventude - PJ; com o Leôncio, o Claudio a Rafaela e Taila,..., lutando com fé, resistindo ao vazio profético, ao vácuo de sentido porque passa a nossa Igreja. Os vejo lutando pelas mesmas causas e contra os mesmos obstáculos para que o Reino aconteça. Os vejo engajados na luta por Educação de Qualidade, para que a justiça e a profecia aconteçam e estejam a serviço do Reino. Os vejo indignados vendo a Igreja distanciar-se da profecia e enclausurar Jesus no Sacrário, como se Ele fosse um ornamento do templo. A religião e a educação a serviço da vida, com a fé que brota e se alimenta da Ressurreição, são instrumentos de libertação. É com eles e nestes espaços também que aprendemos a Ver, a Julgar e a Agir a partir das Escrituras, para transformar a realidade deste nosso tempo cheio de contradições.

Onde uma geração de jovens, com mais de cinquenta milhões de brasileiros/as entre quinze e vinte nove anos, está carente de referenciais políticos, culturais, religiosos e éticos. Sofrem a falta de oportunidades, sobretudo na educação, mas são forçados a acreditar na ladainha da grande mídia, principal púlpito das religiões, que cultura e entretenimento são a mesma coisa; sofrem com as conseqüências da prática de seus pastores que diz que religião e circo se equivalem. Os que não aceitam ser doutrinados e ousam serem profetas/profetizas são colocados à margem. Porque não aceitam ter a Bíblia como um livro de auto-ajuda, ou manual de doutrinamento, como quer o clericalismo triunfalista predominante na Igreja institucional e que insiste em procurar Jesus em Jerusalém. É nas “Galiléias” do mundo que encontramos Jesus ressuscitado, (Mc 16, 7), mas para encontrá-lo precisamos sair de Jerusalém. Jerusalém está disfarçada muitas vezes em palácios e templos cheios de câmeras e tapetes, em pastorais que obedecem a ordens e não a princípios, em "pregadores" que ficam escondidos por de trás de vestimentas litúrgicas vistosas e vendem ilusões e aliciam consciências. Apesar de tudo isto, e da família sofrer a mesma crise relacional porque passa a religião e a sociedade, são ainda os dois principais espaços de pertença da juventude. São os dois lugares que merecem e devem ser resgatados da vala comum aonde estão colocados em nosso tempo. É o que nos ensina pesquisa feita pela 
Secretaria de Educação Continuada - SECAD em parceria com a Organização das Nações Unidas para a Educação, a Ciência e a Cultura - UNESCO,

No Brasil, 96\% dos jovens declaram possuir uma religião (...) e uma das constatações que merece ser sublinhada é o fato de que entre os treze milhões de jovens $(27,3 \%)$ que participam/participaram de organizações sociais o percentual dos que participaram de grupos de cunho religioso é de 81,1\%; cerca de 10 milhões, $22,1 \%$ do total da juventude brasileira. Esse dado expressa a capilaridade social e a disseminada presença da religião e do religioso na sociedade brasileira contemporânea. A participação em grupos religiosos, portanto, pode ser analisada como um importante vetor para a construção de identidades juvenis, representando espaço importante de agregação social nessa fase da vida. (NOVAES e MELLO, 2002). (SECAD/UNESCO, 2009, p. 149).

O que vemos, em consequência da falta de sentido e do excessivo doutrinamento das religiões, é a rotatividade. Quando não é entre denominações diferentes, é dentro da mesma religião. Muda-se de grupo de oração, de pastoral, de paróquia, numa tentativa desesperada de encontrar algo que ajude a dar sentido à vida. O povo está em exílio, sem pátria, sem referências no templo para celebrar a sua fé, e se, por um lado vai ganhando libertação da pobreza econômica extrema que ainda assola milhões de vidas em nosso país, prende-se nas garras da idolatria. Aventura-se nos espetáculos religiosos, nas missas shows, nos shows da fé, comandados por astros da mídia, vestidos a caráter, que tem horror a pobre e vendem indulgências para as sanguessugas da "política" a cada período eleitoral. E até fora deles. Jesus é feito "garoto propaganda" desses ídolos que usam da religião e do sentimento dos fieis para ganhar audiência e valorizar o tempo de propaganda. Via de regra, se não em seus próprios nomes, mas de suas instituições, acumulam fortunas e constroem impérios.

É importante mostrarmos nesta reflexão que, estas escolas não apenas são complementares e interdependentes, mas que às vezes até se confundem de forma que os termos, se trocados de lugar, não causam assombro. Ao contrário, a escola formal é apenas um lugar diferente de aprender. Entre as escolas que mencionamos, esta é a 
única criada artificialmente. O senso comum faz parecer que a educação é sinônimo de escola, dando a entender que educado é quem vai à escola. No entanto, conforme também um dito da sabedoria popular, educação vem de casa. Conforme diz a Conferência Nacional dos Bispos do Brasil - CNBB, “(...) Mencionamos anteriormente que sem educação a geração é um ato imperfeito. Pois bem, afirmamos agora, com a mesma ênfase, que "os pais são os primeiros e principais educadores, e a família, a primeira escola de virtude" (CNBB, DOC. 79, p. 91). Virtude parece-nos algo cada vez mais distante dos conteúdos escolares, sobretudo das relações construídas a partir deles. Da mesma forma que a profecia distancia-se das Igrejas e o diálogo do dia a dia das famílias. Este é o núcleo da crise de sentido de nosso tempo. As escolas não sabem ou não cumprem suas funções específicas e ao Invés de se complementarem, ficam frequentemente uma acusando a outra de não fazer a sua parte. A família que matricula seus filhos na escola ou na catequese, esperando que lá eles sejam "educados" é acusada por ambas de não o fazer em casa. Esquece-se a relação de complementaridade e estabelece-se a competição, quando não a simples culpabilização mútua. Esquecendo-se assim que, como a Igreja, em certa medida, é uma família, também esta de certa forma, é uma Igreja. Igreja Domestica diz o Concílio Vaticano II. Podemos ver isto nas palavras do Papa Bento XVI em sua primeira Carta Encíclica, DEUS CARITAS EST, (Deus é Amor).

A Igreja é a família de Deus no mundo. Nessa família, não deve haver ninguém que sofra por falta do necessário. Ao mesmo tempo, porém, a caritas-agape estende-se para além das fronteiras da Igreja; a parábola do bom samaritano permanece como critério de medida, impondo a universalidade do amor que se inclina para o necessitado encontrado "por acaso" (cf. Lc 10, 31), seja ele quem for. Mas, ressalvada essa universalidade do mandamento do amor, existe também uma exigência de que, na própria Igreja enquanto família, nenhum membro sofra porque passa necessidade. Nesse sentido, pronuncia-se a Carta aos Gálatas: "Portanto, enquanto temos tempo, pratiquemos o bem para com todos, mas principalmente para com os irmãos na fé" $(6,10)$. (DCE, $n^{\circ} .25 b$ ). 
Difícil é encontrar sintonia entre a teologia dos Documentos da Igreja e a teologia praticada pelos palácios da fé. Não menos difícil é fazer da prática da escolavida algo digno de respeito pela instituição Igreja, onde se concentra a essência da religião como escola. Parafraseando um dito popular, parece que o provérbio aqui é: faça o que eu escrevo, mas não faça o que eu faço. A escola é um lugar aonde religiosamente se vai para aprender, mas não é só na escola formal que a gente aprende. A primeira coisa que a escola deve nos ensinar é a perguntar, por quê? Por que aprender matemática? Por que estudar literatura? Que importância tem aprender filosofia? Teologia? Que sentido tem ir à escola? Qual é a diferença entre ir à escola e estudar? Mas nem sempre é assim. A escola formal, como a definimos anteriormente, não gosta que lhe façamos muitas perguntas. É mais prescritiva que dialógica. Ensina mais a obedecer que a pensar. Assim também acontece com as religiões que costumam ensinar mais a ter medo que a amar. Mas o critério de salvação é amar (Mt 25, 33-36). A escola formal tem frequentemente o hábito de isolar-se da escola-vida, alienando-se da realidade e usa a avaliação como forma de castigo. Desperdiça com isto o seu melhor momento de aprendizado, pois para Paulo Freire,

Uma educação em que a liberdade de criar seja viável necessariamente tem de estimular a superação do medo da aventura responsável, tem de ir mais além do gosto medíocre da repetição pela repetição, tem de tornar evidente aos educandos que errar não é pecado, mas um momento normal do processo gnosiológico (FREIRE, 2000, p 100).

Quando não usa os processos avaliativos como justificativa para seus próprios fracassos, sejam pedagógicos ou metodológicos. Sobretudo e de forma intencional, a escola formal, na sua organização, é uma escola de hierarquização social. A própria escola carrega uma carga doutrinal das religiões, já que o sistema de ensino tem muito de sua origem nas religiões, a partir das conhecidas escolas religiosas, ou confessionais. Assim, temos um sistema de ensino dividido em duas categorias. A escola pública e a escola particular. A primeira, com exceção do ensino superior, tem se configurado como um castigo obrigatório, para a maioria da população, que pouco sentido ver nela. A segunda, sobretudo no ensino fundamental e médio, que prepara a classe média para 
dominar, pois é ela quem governa, mandando nas maiorias, a partir de cargos e funções de comando, trata a educação como um produto caro, uma mercadoria rara e de difícil acesso. Como se fosse cotas não legalizadas para brancos e ricos. Por isto é que as escolas particulares, inclusive, neste caso, as universidades, são quais marcas anunciadas e vendidas em campanhas de marketing, que transformam seus "clientes" em vencedores. Verdadeiros super heróis. Faça nosso curso e ganhe o mundo! Em palavras e imagens, inclusive subliminar, propagam, venham, façam nossos cursos e sejam mais um dominador de sucesso. Com a ideia de que saber é poder, as escolas, sobretudo superiores, privilegiam um único saber. $\mathrm{O}$ acadêmico. De onde provém seu maior parceiro, a lei.

A respeito, convém lembrar que a distinção de dominantes e dominados, passada em seguida para a nossa cultura, tem sua origem na escola pitagórica. Arquitas de Taranto escreve: "Toda sociedade é formada de dominante e dominado: por isto, como terceiro elemento intervém a lei". (MANACORDA, 2006, p. 41).

A escola tem dificuldade de superar sua lógica e que também constitui sua maior contradição que é, de certa forma, legitimar uma sociedade de dominantes e dominados. Talvez este seja o resultado direto da relação mantida e alimentada que trata a sociedade divida em duas categorias. Uma que sabe e outra que não sabe. Saber neste caso, necessariamente, significa ter passado por seus bancos, aceitado suas normas sem contestar e concordar em reproduzi-las. Para ela a vida não é escola, a família, no máximo, é uma parceira estratégica para suas formalidades e a sabedoria popular não passa de uma bobagem. A escola é assim, um lugar de teoria sem uma prática que lhe dê sentido. Nega-se assim os saberes empíricos como se pudessem existir como teoria sem eles.

A escola fica dia a dia cada vez mais conteudista, resume as metodologias que até diz fazer uso, a meras técnicas de ensino. Nem são de aprendizado. Ensina-se cada vez mais na escola a ensinar e cada vez menos a aprender. Como se isto fosse possível. "Quem ensina aprende ao ensinar e quem aprenda ensina ao aprender" (FREIRE, 2004, p. 30). Os saberes vividos, assim como as experiências vivenciadas, não cabem nas sistematizações, estas são tentativas válidas, é verdade, e também significativas formas 
de registrá-las, de estudá-las e assim melhor entendê-las. São teorizações, tem seu significado e sua razão de ser, mas não podem substituir e tampouco superar a realidade pesquisada, como às vezes se faz parecer.

Pode-se chamar de saberes experienciais o conjunto de saberes atualizados, adquiridos e necessários no âmbito da prática da profissão docente e que não provém das instituições de formação nem dos currículos. Estes saberes não se encontram sistematizados em doutrinas ou teorias. São saberes práticos (e não da prática: eles não se superpõem à prática para melhor conhecê-la, mas se integram a ela e dela são partes constituintes enquanto prática docente) e formam um conjunto de representações a partir das quais os professores interpretam, compreendem e orientam sua profissão e sua prática cotidiana em todas suas dimensões. Eles constituem, por assim dizer, a cultura docente em ação (TARDIF, 2005, p. 48/49).

Além da ideologia de dominação, os muros que frequentemente deixam as escolas mais parecidas com presídios, onde quem está dentro não ver quem está fora e quem está fora não tem a menor ideia do que acontece lá dentro, se encarregam de legitimar a negação de outros saberes. As escolas, sobretudo, as particulares fazem hoje, ao estabelecer uma reserva de mercado do conhecimento e vendê-lo à conta gotas, entregando-o em forma de diploma e certificação, com suas marcas timbradas, aquilo que a Igreja fazia com as escrituras em tempos não muito remotos. É preciso que as instituições apareçam menos e os saberes, assim como o seu emprego a serviço da transformação da sociedade apareçam mais.

$\mathrm{Na}$ hierarquização social, por conseguinte, esconde-se a realidade da prática da leitura ou se torna irreconhecível. Ontem, a Igreja, instituindo uma ruptura social entre clérigos e "fiéis", mantinha a Escritura no estatuto de uma "letra" supostamente independente de seus leitores e, de fato, de posse dos seus exegetas: a autonomia do texto era a reprodução das relações socioculturais no seio da instituição cujos pressupostos fixavam o que se deveria ler na Escritura. Com o 
enfraquecimento da instituição, aparece entre o texto e seus leitores a reciprocidade que ela escondia, como se, em se retirando, ela permitisse a pluralidade indefinida das "escrituras" produzidas por diversas leituras. A criatividade do leitor vai crescendo à medida que vai decrescendo a instituição que a controlava (CERTEAU, 2011, p. 243, .).

Além da hierarquização, seja ela a social citada acima ou aquela reproduzida na sociedade, que faz com que parcela significa dos pouco mais de dez por cento que entram na universidade, saiam sem saber interpretar um texto, consequentemente sem saber escrever, existe a fragmentação do saber. Em certa medida acontece um encontro em nosso tempo entre esta visão que não é pessimista e nem é criticista, é realista e crítica, pelo menos tem esta intenção e que se apresenta neste texto, e a grande mídia nacional. Se, para a escola formal, educação é aquilo que ela faz, para a grande mídia, cultura é aquilo que ela transmite. Com isto ficam o saber e a cultura populares renegados e fora das "caixinhas", apesar de dar sentido e significado à vida do povo, sofrem absurdas discriminações. Já na religião isto acontece quando ela diz através de diversas formas e linguagens, que Deus está preso, é refém de seu ritualismo e de seus rubricismos sacramentais, e só pode ser encontrado dentro de seus templos. O povo até pode entrar lá, mas desde que apenas escute, nada fale e principalmente obedeça. A cultura popular é censurada especialmente na liturgia, pois tudo o que ela representa, para o liturgismo intolerante, é ante litúrgico. Mas, o que é o povo? O que é a cultura popular?

(...) Por exemplo, se a cultura popular é a "cultura do povo", quem é o povo? São todos: o pobre, as "classes subalternas", como costumava chamá-las o intelectual marxista Antonio Cramsci? São os analfabetos ou os incultos? Não podemos presumir que as divisões econômicas, políticas e culturais em uma determinada sociedade necessariamente coincidam. E o que é educação? Apenas o treinamento transmitido em algumas instituições oficiais como escolas ou universidades? As pessoas comuns são ignorantes ou simplesmente tem uma educação diferente, uma cultura diferente das elites? (BURKE, p. 21). 
É fato que existe uma confusão, ou um equívoco naturalizado que confunde analfabeto com ignorante e o analfabetismo como uma praga. Que na pressa de transferir conhecimentos, esquece-se que o objetivo da educação é produzi-lo, e que todos nós somos capazes e produzimos conhecimentos. Todavia, essa produção, no meio popular, apesar de existir, não é reconhecida, talvez porque não seja registrada. A cultura do povo, neste caso a cultura popular, entendida no sentido gramsciano, não cabe nas tais "caixinhas" que as elites usam para guardar ou exibir aquilo que para elas é a cultura. Entre essas caixinhas está a televisão. A cultura que é ensinada na televisão, muitas vezes, não passa de um arremedo da cultura popular, da cultura do país, que dar, conforme já foi dito, sentido à vida e à fé do povo, as classes subalternas, que fazem cultura, vivem a fé, lêem o mundo, a partir de sua realidade. Com a sua linguagem e com os seus interesses também. E é justamente por isso que a vida é a primeira e a mais significativa escola que temos. Para o povo, neste sentido, aprender e ensinar estão intrinsecamente relacionados com o viver. Como Gramsci, Paulo Freire também teve esta percepção,

Ensinar e aprender são assim momentos de um processo maior - o de conhecer, que implica reconhecer. No fundo, o que eu quero dizer é que o educando se torna realmente educando quando e na medida em que conhece, ou vai conhecendo os conteúdos, os objetos cognoscíveis, e não na medida em que o educador vai depositando nele a descrição dos objetos, ou dos conteúdos (FREIRE, 2009, p. 47).

Na educação, conforme descrita acima, não existem momentos estanques, nem saberes absolutos. $\mathrm{O}$ ato de ensinar e aprender dá-se numa relação dialética e complementar, onde um já não pode ser sem o outro. Bem diz a sabedoria popular, "É vivendo e aprendendo". É este saber de experiência feito que permite a possibilidade de vida das grandes maiorias isoladas nas periferias das cidades, ou nos rincões do país, e que são deserdadas das conquistas trazidas pelos conhecimentos científicos. Não fosse, não apenas o fato destes conhecimentos transmitidos de pai para filho, de mãe para filha, em inúmeras gerações, como por exemplo, as parteiras e as benzedeiras, mas, sobretudo, a partilha e a solidariedade com as quais eles se dão, talvez a própria história humana fosse outra bem pior. Ou pelo menos bem diferente. É aqui que surge a nem tão 
sutil diferença entre o professor formal, o cientista frio ou o técnico da escola formal, e aquele mestre amoroso da escola-vida, aquela mestra, cuidadosa da escola-família.

Os saberes experienciais estão enraizados no seguinte fato mais amplo: o ensino se desenvolve num contexto de múltiplas interações que representam condicionantes diversos para a atuação do professor. Esses condicionantes não são problemas abstratos como aqueles encontrados pelo cientista, nem problemas técnicos como aqueles com os quais se deparam os técnicos e tecnólogos. O cientista e o técnico trabalham a partir de modelos e seus condicionantes resultam da aplicação ou da elaboração desses modelos. Com o docente é diferente. No exercício cotidiano de sua função, os condicionantes aparecem relacionados a situações concretas que não são passiveis de definições acabadas e que exigem improvisação e habilidade pessoal, bem como a capacidade de enfrentar situações mais ou menos transitórias ou variáveis (TARDIF, 2005, p. 49).

Quando a escola torna abstratos os problemas reais, situação não rara de se ver, inclusive com a própria realidade concreta sendo substituída ou negada, tem-se a situação contraditória de professores que desconhecem como vivem seus "alunos". Acreditam, ou são levados a acreditar, que podem estabelecer entre eles uma relação de aprendentes, mas o máximo que conseguem é transferir ou depositar conteúdos e conceitos prontos. O professor, neste sentido, não responde presente, quando chamado de pesquisador, pois, para a escola formal, ensino e pesquisa são coisas diferentes, tratadas em departamentos separados e por profissionais diversos. Igualmente se dar com relação a aprender e ensinar. As organizações políticas que tratam da educação e de seus agentes, também perderam este sentido de educação como construção e produção coletiva do conhecimento. Afogaram-se em seus corporativismos e tiraram o sonho e a utopia, como energia propulsora da curiosidade epistemológica, de seus planos de aula. Isto quando existem planos de aulas, já que a regra ainda é o improviso. Assim como aconteceu com a religião cristã, onde o ser cristão é mais exigente que simplesmente freqüentar os cultos, mas construir pertença, a educação precisa admitir que estudar é mais que ir à escola. 
A profissionalização exige mais que aprender decorando conteúdos, por mais que eles sejam necessários. É neste sentido que defendemos a ideia de escolas de fé e a necessária fé nas escolas. Desmitificar a ideia de fé, como se ela fosse uma questão restrita às religiões ou por vezes apenas às Igrejas, e que a educação se aprende apenas indo à escola, que ela diz respeito à escola apenas. Assim, conforme já foi dito, a escola aprendeu muito com as religiões, pois tem em grande parte, sua origem nelas, e repete este aprendizado, de forma explícita quando se prende ao doutrinamento. Às vezes temos a impressão que para a escola formal e para as religiões, ainda não saímos do regime autoritário. A pluralidade de ideias, a abertura para novas concepções e novas formas inclusive de aprender, são exigências de todos os tempos, mas condição irrenunciável de nosso tempo. A profissionalização de professores carrega uma carga doutrinal com fortes características da educação religiosa medieval, que conforme diz Dominique Julia,

Uma das figuras desta profissionalização ocorre quando a antiga cristandade se desmembra em confissões plurais e nos países católicos, na dinâmica que segue o Concílio de Trento: ser cristão não é mais, como nos séculos passados, somente pertencer a uma comunidade, manifestando-se como tal, mas ser capaz de proclamar pessoalmente as verdades da fé e ser instruído sobre as verdades da religião (DOMINIQUE, 2001, p.25).

Além disto, não basta ser capaz de professar as verdades da fé, é condição irrenunciável, testemunhar na vida estas verdades. Seria interessante sabermos o que pensam disto os estudantes. Por que eles vão à escola? O que esperam dela? Que sentido tem para eles ir à escola? É por isto que apresentamos a relação de complementaridade das escolas na formação do ser humano para a vida. A maior notícia que as nossas escolas receberam foi a política de cotas. Elas significam o reconhecimento de uma injustiça cometida há séculos, pelo Estado, a partir daquilo que é a sua maior responsabilidade no Estado moderno. A educação. As religiões pouco ou nada se envolveram na defesa desta política. Mesmo sendo ela um lampejo profético e um sinal de justiça. A exclusão de imensas maiorias do acesso à escola é a mãe de todas 
as outras injustiças que compõem a grande lista de malvadezas das políticas públicas brasileiras.

Cabe ao Estado promover e incentivar políticas de reparações, no que cumpre ao disposto na Constituição Federal, Art. 205, que assinala o dever do Estado em garantir indiscriminadamente, por meio da educação, iguais direitos para o plano de desenvolvimento de todos e de cada um, enquanto pessoa, cidadão ou profissional. Sem a intervenção do Estado, os postos à margem, entre eles os afro-brasileiros, dificilmente, e as estatísticas o mostram sem deixar dúvidas, romperão o sistema meritocrático que agrava desigualdades e gera injustiça, ao reger-se por critérios de exclusão, fundados em preconceitos e manutenção de privilégios para os sempre privilegiados (MEC/SECAD, 2006, p.232).

Quando se nega a uma geração de jovens o direito à educação, nega-se não somente a ele, mas à nação a qual ele pertence um futuro que não seja uma sina. Uma educação do faz de conta, como ouvimos frequentemente nas conversas do dia a dia, e até vemos sem muita dificuldade, onde as condições de trabalho são precarizadas e o Estado finge que paga e os/as professores/as fingem que trabalham, é a vida que perde. $\mathrm{Na}$ verdade, é bom que se diga, esta é uma afirmação injusta. A maioria dos/as professores/as trabalha muito! E trabalha em condições desumanas, com poucos incentivos, como formação e atualização, bem como com salários irrisórios. A consequência imediata desta realidade é outra relação entre uns que fingem ensinar e outros que fingem aprender. E, neste caso, por desmotivação mútua. A educação é o que comprova a vida como vocação. A escola e nem mesmo o sistema educacional brasileiro, incluindo os sindicatos da educação, não foi ainda capaz de discutir a política de cotas com a devida e merecida seriedade. Fica-se na tábua rasa sempre conveniente, do deixar como está para ver como fica, mas insuficiente, do contra e a favor. É difícil encontrar alguém que tenha argumentos consistentes contra as cotas e que ao tentar utilizá-los não caia em flagrante contradição, revelando assim a fragilidade dos mesmos. Dois pontos de referência oferecem as duas janelas por onde se formam as opiniões a este respeito. Quem olha e avalia a partir da Casa Grande é contra as cotas e cruelmente até as ver como uma forma de discriminação contra os negros. Por outro lado, quem as olha a partir da senzala, é a favor, as ver como reconhecimento e tentativa de correção 
de uma injustiça histórica, como o mínimo que se pode fazer. Como começo do fim de uma distorção. O ser humano visto e entendido como um ser político, religioso e fazedor de cultura, é também e, sobretudo, um ser sujeito de direitos. E é isto que também diferencia os pontos de vistas. Os direitos são para todos, sem distinção de raça, de credo, de cor, de sexo, ou de geração. Porém, parafraseando outro dito popular, na prática a teoria é bem diferente.

Ao existir, qualquer indivíduo já está automaticamente produzindo cultura, sem que para isto seja preciso ser um artista, um intelectual, ou um artesão. A própria linguagem, e as práticas discursivas que constituem a substância da vida social, embasam esta noção mais ampla de cultura (BARROS, 2004, p. 57).

Se não podemos admitir um saber maior ou menor que outro, mas que todos os saberes são importantes e diferentes; que uma religião não é mais ou menos importante que outra; que não existe família igual a outra, sendo a diversidade, uma característica da natureza; mas que cada uma, como escola, traz significados diferentes. Que tudo isto, por fim, está relacionado com a cultura em que se vive e que já não podemos pensar, se não nas culturas, que além de plurais, ainda mudam no correr do tempo. A escola-vida se faz vida-escola, quando o diferente é fonte de riqueza, significa antes a pluralidade do universo e não é reduzido ao desigual. Os/as grandes mestres/as, de todas as artes, nos ensinam isto com seus exemplos. O escultor, portanto, assim como o carpinteiro e o pedreiro, escreve uma história quando esculpe sua arte, seja no mármore ou na madeira, o escritor igualmente esculpe as formas de sua cultura, os traços de sua fé quando faz sua história literária e o poeta faz sua oração e o místico faz sua poesia quando transmite em seus escritos sua visão de mundo e de ser humano no mundo. Ambos transcendem à sua maneira o universo do outro e todos se encontram em dado momento. É o que nos faz pensar Mário Alighiero Manacorda em sua história da educação,

“(...) Além disso, eu também acho que a arte de escrever não é diferente da arte de esculpir, que para Miguel Ângelo consistia em suprimir o inútil e o excesso ao redor da figura essencial oculta no mármore: também escrever no escrever é preciso alcançar o essencial" (MANACORDA, 2006, p. 7). 
É o que se espera ter conseguido neste texto, quando chegarmos ao seu final. Aparado as arestas, os excessos sem comprometer a obra e evidenciado o essencial. Mostrado os contornos nem sempre mostrados da educação a partir das três principais escolas que formam a escola-vida. A relação de complementaridade entre os saberes, as escolas, as culturas e que, do ponto de vista do ser humano, nada disto é possível sem uma fé. As religiões, vistas como escolas de fé, tornam a educação um ato muito mais exigente, pois, assim dão a ela aquilo que não lhe pode faltar, sentido. A escola precisa rever urgentemente alguns de seus conceitos, sob pena de descaracterizar-se ainda mais. Três pelo menos não podem ficar de fora desta reflexão, já que não é seu objetivo aprofundar sobre todos eles. O primeiro e mais urgente, por razões obvias, são as relações estabelecidas entre os agentes que fazem a educação na escola no seu dia a dia. Com prioridade e urgência para as relações professor/a aluno/a; a segunda, porém não menos importante, apenas, imagina-se, dependente da primeira, são as metodologias. Precisam considerar uma relação entre seres que sabem e sabem saberes diferentes, mas, mesmo assim, por isso mesmo, uma relação entre aprendentes; a terceira são os processos avaliativos. Precisam assumir a condição de momento pedagógico de excelência para o aprendizado. A partir da compreensão da avaliação como momento de aprender e não de punir ou simplesmente justificar atitudes, aprender deixará de ser um privilégio e se tornará uma vocação.

\section{Considerações finais}

É essa a hora de convidarmos todos nós para uma reflexão sobre a vida e suas escolas. É este o convite feito neste artigo. O que tivemos aqui, no entanto, foram um olhar e uma opinião, a partir de um determinado ponto. Alguém que se postar em outra posição poderá ter outras impressões. Sobre tudo se tiver outros interesses. Isto não valida uma ou invalida outra opinião. Até porque a realidade não cabe em um único olhar, por mais privilegiada que seja a sua vista. Não tivemos também essa pretensão, mas de contribuir com outros olhares, enriquecer outras impressões e, por fim, exercer o dever de dialogar franca e fraternamente sobre a vida, sobre a educação para a vida e seus processos. Viver, no entanto, é mais que falar, assim como sentir é mais que simplesmente imaginar. A educação como mercadoria, exige que os/as professores/as sejam vistos e tratados como vendedores/as de ilusões e os potenciais aprendentes, 
sejam resumidos a meros clientes. E muitas vezes um cliente virtual que raramente consegue interagir com alguém que não as "caixinhas" eletrônicas dos sites com suas impessoalidades e friezas. São ferramentas de nosso tempo, apenas isto. Não substituem nem prescindem da relação afetiva e efetiva, que faz o ser humano ser mais. As religiões, por sua vez, adotam fórmulas mercantilistas modernas, onde os pastores, com nomes que se resumem a funções, (padres, bispos, missionários, obreiros, cardeais...), não passam de burocratas da fé, que não sabem ouvir, não sabem sorrir - às vezes fingem por conveniência - e muitas vezes não sabem nem rezar. Abandonaram o sentido de pastor. Somente uma teologia leiga, capaz de ler os sinais dos tempos e as realidades sócio políticas e econômicas, mas também espirituais, sem dicotomizar suas funções, poderá dar início a uma nova visão de mundo, de ser humano e de fé a toda a Igreja. Isto é vital para a própria Igreja. A família, bem a família, guardadas as devidas ressalvas, vai bem, obrigado. Obedece a Igreja naquilo que lhe convém, vive brigando com a escola porque ela é cada vez menos eficiente no ato de ensinar, sobretudo a aprender, e continua escola de vida. A família também não cabe no conceito estreito em que, principalmente a Igreja quer lhe prender. Por vocação e necessidade continua sendo escola para as religiões e para as escolas formais. Cabe a elas quererem aprender a aprender.

\section{Referenciais}

- BARROS, José D`Assunção. O Campo da História: Especialidades e abordagens. Petrópolis-RJ: Vozes, 2004.

- BENTO XVI. DEUS CARITAS EST. Carta Encíclica do Sumo Pontífice bento XVI, aos Bispos, Presbíteros e Diáconos, às Pessoas Consagradas e a Todos os Fiéis Leigos, Sobre o Amor Cristão.

- BÍBLIA. Bíblia Sagrada, Tradução Ecumênica da Bíblia - TEB - São Paulo: Loyola, 1994. 
- BURKE, Peter. A Escrita da História: novas perspectivas/ (org.); tradução de Magda Lopes - São Paulo: Editora da Universidade Estadual Paulista, 1992.

- CERTEAU, Michel de. A invenção do cotidiano: artes de fazer. Petrópolis-RJ: Vozes, 2011.

- CNBB - Conferência Nacional dos Bispos do Brasil. Diretório da Pastoral Familiar. Documento 79. São Paulo: Paulinas, 6. ed. 2009.

- DOMINIQUE, Júlia. A Cultura Escolar como Objeto Histórico. Revista brasileira de História da Educação. (pg. 9 - 43) No. 1 jan./jun. 2001. Sociedade Brasileira de História da Educação - SBHE. Editora Autores Associados - Campinas-SP, 2001.

- FREIRE, Paulo. Pedagogia da Autonomia. São Paulo: Paz e Terra, versão Anca/MST, 2004.

- FREIRE, Paulo. Pedagogia da Esperança: um reencontro com a Pedagogia do Oprimido. São Paulo: Paz e Terra, 16. ed. 2009.

- FREIRE, Paulo. Pedagogia da indignação: cartas pedagógicas e outros escritos. São Paulo UNESP, 7. reimpressão, 2000.

- MANACORDA, Mário Alighiero. História da Educação: da Antiguidade aos nossos dias. São Paulo: Cortez, 12. ed. 2006.

- MEC/SECAD. Ministério da Educação. Secretaria de Educação Continuada, Alfabetização e Diversidade. Orientações e Ações para a Educação das Relações Étnico-Raciais. Brasília-DF: SECAD, 2006.

- PAUlO VI. POPUlORUM PROGRESSIO. Carta Encíclica de Sua Santidade o Papa Paulo VI Sobre O Desenvolvimento dos Povos. São Paulo; Paulinas12. ed. 1990. 
- SECAD, Secretaria de Educação Continuada, Alfabetização e Diversidade. Juventudes: outros olhares sobre a diversidade. Coleção Educação para Todos. Brasília, 2009.

- TARDIF, Maurice. Saberes docentes e formação profissional. Petrópolis-RJ: Vozes, 5. ed. 2005.

Recebido:25/05/2013

Received: 05/25/2013

Aprovado: 04/07/2013

Approved: 07/04/2013 